\title{
ANALIZA TEKSTÓW LITERACKO-MUZYCZNYCH NA STUDIACH WYŻSZYCH (?) NA PRZYKŁADZIE WIERSZY STANISŁAWA BARAŃCZAKa
}

\author{
Paulina Łopatka-Koneczny \\ Instytut Muzykologii, Uniwersytet Wrocławski \\ ul. Szewska 36, 50-139 Wrocław \\ Instytut Filologii Polskiej, Uniwersytet Wrocławski \\ pl. Biskupa Nankiera 15b, 50-140 Wrocław, Polska \\ E-mail: paulina.lopatkakoneczny@gmail.com \\ ORCID: https://orcid.org/0000-0001-5126-3562
}

\section{Abstrakt}

Cel badań. Ukazanie sposobów i możliwości wykorzystania różnego typu metod badawczych służących analizie i interpretacji tekstów poetyckich, które zawierają elementy muzyczne (odwołania, cytaty muzyczne, interteksty).

Metody badań. Analiza tekstów naukowych traktujących o utworach literacko-muzycznych. Analiza filologiczna i muzykologiczna wierszy Barańczaka. Elementy metody heurystycznej.

Wyniki badań. Można odnotować badania łączące muzykologiczne i literaturoznawcze metody analizy tekstów, lecz jest ich niewiele. Z uwagi na występowanie tekstów pogranicznych, eksperymentalnych istnieje potrzeba kształcenia, które z gruntu byłoby interdyscyplinarne. Wiersze Stanisława Barańczaka (1994) (szczególnie te, pochodzące z tomu Podróż zimowa) powinno się badać dwutorowo: muzykologicznie i filologicznie, by móc je poddać interpretacji. Wykorzystywanie $w$ badaniach omawianych tekstów wyłącznie jednej z metod nie daje pełnego obrazu dzieła i pozbawia je zasadniczego kontekstu.

Wnioski. Do właściwej interpretacji wierszy, które uwikłane są w muzyczne konteksty, potrzebne są analizy interdyscyplinarne, łączące metody literaturoznawcze i muzykologiczne. Niestety tego typu analiz jest niewiele.

Słowa kluczowe: analiza filologiczna, analiza muzykologiczna, poezja, muzyka, Stanisław Barańczak.

Analysis of literary-musical texts by a University student, on the example of poems by Stanisław Barańczak

Abstract

Aim. To show the ways and possibilities of using various research techniques to analyze and interpret poetic texts including musical elements (references, musical quotes, intertexts) 
Methods. Analysis of scientific texts on literary-musical compositions. Philological and musicological analysis of poems by Barańczak. Elements of the heuristic method.

Research. There is very little research connecting musicologist and literature-specialist methods of text analysis. Due to the existence of interdisciplinary and experimental texts, education of the subject also needs to be interdisciplinary. The poems of Stanisław Barańczak (particularly those from the volume Winter Journey ) need to be studied double-sided - musicologically and literature-scientifically - in order to interpret them. When only one of the methods is used, we cannot see the full picture of the work.

Conclusions. To interpret poems including musical context properly, interdisciplinary analysis connecting literature-scientific and musicological methods are needed. Unfortunately, there are very few such methods.

Key words: philological analysis, musicological analysis, poetry, music, Stanisław Barańczak

\section{SPORY}

Na wstępie zaznaczę, że obszar badań związany z relacjami muzyki i literatury nadal - mimo coraz liczniejszych głosów naukowców zajmujących się tymi problemami - jest pełen niejasności, nieścisłości i błędnie wysnuwanych przez analogię porównań. Niniejszy wywód jest zatem jedynie przyczynkiem do dalszych, pogłębionych rozważań dotyczących tekstów literacko-muzycznych.

Osoby decydujące się na opis fenomenów muzyczno-literackich czy literacko-muzycznych nadal poszukują odpowiednich metod i sposobów mówienia o interdyscyplinarnych zjawiskach. Stanowiska badaczy bywają rozbieżne. Dyskurs nie dotyczy wbrew pozorom wyłącznie związków obu dziedzin, lecz także niemożności połączenia metod muzykologicznych z filologicznymi. Nierzadko poruszane są kwestie zjawisk granicznych, których badanie częstokroć okazuje się nieskuteczne z uwagi na brak narzędzi dostosowanych do tego celu. W tekstach naukowych zazwyczaj powiela się wątpliwości dotyczące przekładu intersemiotycznego, efemeryczności muzyki, braku odpowiedników w systemie znakowym obu dyscyplin przy równocześnie oczywistej analogii występowania niektórych środków wyrazu. W opracowaniach naukowych często pojawiającymi się terminami są: intermedialność, intertekstualność, komparatystyka interdyscyplinarna, intersemiotyczność, muzyka jako interpretant - przytaczany za Głowińskim (2002) i Nyczem (1990). Już ten zestaw świadczy o bardzo różnym podejściu do badanego tematu i sugeruje, że problem opisu zjawisk pogranicznych literacko-muzycznych nie został rozwiązany. W rezultacie możemy mówić eo ipso o metodologicznym rozproszeniu, a nawet o sporze, który obejmuje sposoby badania zjawisk pogranicznych. Dzieje się tak, ponieważ „wprowadzanie muzyki w przestrzeń słowa ma ograniczony zakres" głównie ze względu na odmienny system znakowy (Reimann, 2012, s. 140), a tym samym wymaga precyzji terminologicznej.

Magdalena Lachman i Jerzy Wiśniewski we wstępie do numerów tematycznych „Folia Litteraria Polonica” poświęconych fenomenom literacko-muzycznym piszą: „Jednocześnie bez trudu przychodzi badaczom płynne oscylowanie między różny- 
mi poziomami komunikacyjnymi i sferami budowy rozpatrywanych przekazów artystycznych. Tam, gdzie główny punkt ciężkości ogniskuje się na sztuce słowa, komentatorzy chętnie koncentrują się na stematyzowanych nawiązaniach do muzyki na poziomie treści utworów, ale równocześnie odnajdują inspiracje muzyczne w ich warstwie brzmieniowej czy formalnym ukonstytuowaniu, rozpatrując choćby hipotezy o przekładalności struktury fugi czy suity na kompozycję dzieł literackich, przy okazji zaś testują też przydatność terminologii o rodowodzie pozaliteraturoznawczym - na przykład zastanawiają się nad poręcznością i operacyjnością pojęcia dynamiki w znaczeniu stricte muzykologicznym przy analizie poezji albo akcentują zasadność wprowadzenia do rozważań nad piosenką kategorii melosemii (polegającej na uwypuklaniu znaczeń tekstu literackiego za sprawą świadomie zastosowanej melodii i konkretnego muzycznego wykonania)" (Lachman i Wiśniewski, 2012, s. 6).

Już na tym przykładzie widać, jak wiele zmieniło się w świadomości literaturoznawców piszących o muzyce $\mathrm{w}$ tekstach literackich. Bezrefleksyjne przenoszenie terminów typu dysonans czy crescendo na grunt literatury w zupełnym oderwaniu od znaczenia, które pełnią te terminy $\mathrm{w}$ muzyce, nie może mieć miejsca $\mathrm{w}$ badaniach naukowych. Warto zwrócić uwagę na kwestię foniczności czy audialności literatury, której materia czasem przypomina zjawiska muzyczne ze względu na budujące ją tworzywo dźwiękowe. Nie zapominajmy, że realizacja parole odbywa się nie tylko jako imaginacja systemu langue, ale także za sprawą dźwięków.

\section{TEORIA}

Analiza utworu literacko-muzycznego może być bardziej lub mniej szczegółowa. Zależy to nie tylko od wiedzy badacza, która obejmować powinna zakresy obu dyscyplin, jego umiejętności interpretacyjnych; ale też od samego tekstu literackiego, który zwykle zawiera różnorakie typy odniesień muzycznych. W tym sensie możemy uznać za Ryszardem Nyczem, że dzieło jest ,,intertekstualnym konstruktem”, , ,efemerycznym splotem heteronomicznych właściwości dyskursywnych" (1990), palimpsestowo zapisaną kartą. Co zatem oczywiste przy badaniu takich utworów konieczne jest uwzględnienie perspektywy muzykologicznej i literaturoznawczej. Badacz musi skutecznie lawirować pomiędzy zjawiskami charakterystycznymi dla danej dziedziny i uchwycić ich związek ze strukturą interpretowanego dzieła. Taka strategia wymaga korelacji wiedzy z zakresu zarówno teorii i historii literatury oraz teorii i historii muzyki (lub dotarcia do opracowań, artykułów, publikacji naukowców zajmujących się danym tematem), oraz symultanicznego wykorzystania obu analiz muzycznej i filologicznej.

Jak powiada Aleksandra Reimann: „Gdy podejrzewamy tekst literacki o związek z tekstem muzycznym (lub systemem muzycznym), koncentrujemy się na kilku podstawowych pytaniach, które pojawiają się już na początku analityczno-interpretacyjnych dociekań:

- Skąd zostały zaczerpnięte elementy budujące dialog między sztuką słów i sztuką dźwięków,

- W jaki sposób są one sfunkcjonalizowane w strukturze dzieła,

- Jaki mają wkład w semantyczne wyposażenie utworu.

Ogrody Nauk i Sztuk nR 2020 (10) 
Pytania te - powiedzmy od razu - projektują pewien schemat postępowania, który od rozpoznania muzycznej wskazówki, czyli muzycznego interpretanta, prowadzi do muzycznego horyzontu oczekiwań odbiorczych (muzycznego stylu odbioru)" (Reimann, 2012.s. 143).

W związku z tym musimy wziąć pod uwagę oba działa: muzyczne oraz literackie i opracować odpowiednią dla interdyscyplinarnego utworu metodę. Analiza będzie przyjmowała rozmaite formy, w zależności od tego, jakie relacje i elementy zawiera główne dzieło. Musimy ustalić, czy mamy do czynienia z literackim tekstem skonstruowanym za pomocą technik kompozytorskich, czy jest to forma stylizacji na muzyczny odpowiednik, czy tematyzacja muzyki w literaturze, czy konkretne nawiązanie itd. Przy czym odwołanie zawsze musi być przez autora tekstu zamierzone, co podkreśla chociażby Głowiński (2002).

Tekst słowny adaptuje struktury muzyczne różnorako, a więc rodzaje oddziaływań obu dziedzin przybierają rozmaite formy: muzyka może stanowić element fikcji literackiej; tekst może posiadać „muzyczny tytuł”; w dziele mogą pojawić się tematyzowane muzyczne odniesienia (instrumenty, zapis nutowy, fragmenty lub tytuły książek o muzyce, bohater może być kompozytorem, śpiewakiem, sławne nazwisko muzyka, terminy muzyczne); utwór może być skonstruowany tak, by wywołać dane wrażenie słuchowe bądź akustyczne ( $w$ wierszu takie wrażenie potęgują środki stylistyczne typu aliteracja, rym, instrumentacja głoskowa, asonanse, itp.); struktura tekstu może być oparta na danej formie muzycznej lub innej muzycznej konstrukcji (Opalski, 2002; Dą̧rowski, 2002).

Dodajmy, że forma wiersza jest doskonałą kanwa, na której tworzą się nie tylko znaczenia, ale i różne nawiązania, sprzężenia intermedialne. W starożytności poezja, muzyka i taniec były nierozdzielne, jednoimienne, pisarzy zwać można było także muzykami, a odróżnienie elementów tych dziedzin zdawało się niewykonalne. Poezja była bowiem jednocześnie muzyką i tańcem. Dla przykładu - dytyramb jest pieśnią i utworem literackim, który ma charakter taneczny, o czym stanowi przecież nomos. Wiersz meliczny wydaje się najbardziej muzycznym przez to, że jest ściśle uporządkowany wewnętrznie, jak utwór muzyczny.

Proponuję zatem uwzględnienie analizy muzycznej obok analizy filologicznej już w początkowej fazie badań. Owa analiza polega na rozłożeniu struktury muzycznej na względnie proste elementy składowe i badaniu ich funkcji w ramach tej struktury. Trzeba sobie uświadomić, że muzyka również posiada swoistą gramatykę, którą rozumiem jako zbiór zasad, formalnych rozwiązań i możliwości wykorzystania ich w praktyce, czyli wykonania utworu muzycznego. Analizę zwykło się dzielić na: formalna, harmoniczna, melodyczną oraz dynamiczną. Formalna dotyczy oczywiście formy dzieła; harmoniczna obejmuje zagadnienia związane z systemem dur-moll, ale także te, które dotyczą innych systemów tonalnych oraz atonalności. Zwykle stosuje się metody analizy i zapisu oznaczeń funkcyjnych opracowane przez Kazimierza Sikorskiego oraz Franciszka Wesołowskiego, a także Hermanna Erpfa. Analiza melodii opiera się głównie na rozpoznaniu jej rodzaju (kantylenowa, figuracyjna, deklamacyjna lub ornamentalna) i dostrzeżeniu funkcji.

Chodzi o to, by zauważyć i nauczyć się czytać utwory literacko-muzyczne nie tylko linearnie, ale też wertykalnie, jak częstokroć czytamy partytury muzyczne. Od 
strategii przyjętej przez badacza zależy znalezienie elementów wertykalnych w dziele (mogą to być bowiem wszelkie muzyczne odnośniki). Należy sobie także zdać sprawę $\mathrm{z}$ tego, że analiza tekstu o takim charakterze zawsze będzie miała, chociażby w najmniejszym stopniu, wymiar metaforyczny, który jest widoczny chociażby w stwierdzeniach typu: „wymowność muzyki”, „muzyczność tekstu”, oraz jest wynikiem znajdowania analogii między systemami znaków: muzycznym i literackim.

\section{Praktyka}

W tej części zawarte zostały analizy bardziej i mniej skomplikowane, przy czym stopień zgłębienia muzycznych odniesień determinowany jest przez sam tekst (podobne analizy poczyniłam w mojej pracy licencjackiej o tytule: Muzyka w poezji na przykładzie wierszy Stanistawa Barańczaka z tomów: 'Podróż zimowa' i 'Chirurgiczna precyzja' napisanej na kierunku filologia polska na Uniwersytecie Wrocławskim). Na początku poddany analizie został utwór literacko-muzyczny, który jest wysoce umuzyczniony, ponieważ napisano go na bazie rzeczywistej muzycznej kompozycji, jest także próbą translacji wrażeń akustycznych, opiera się na inspiracji formalno-kompozycyjnej i charakteryzuje się powszechnie pojmowaną melodyjnością (chodzi o swoistą brzmieniową organizację tekstu). Opracowaniem zawierającym wyjątkowo rozbudowane analizy zjawisk muzyczno-literackich, które traktuję jako pewien model analizy par excellence jest książka Andrzeja Hejmeja Muzyczność dzieła literackiego (2002, ss. 124-165).

Podróż zimowa składa się z dwudziestu czterech pieśni napisanych do muzyki skomponowanej przez Franza Schuberta, natomiast Winterreise - op. 89, D 911 (zob. ryc. 1) powstała w 1827 roku do wierszy Wilhelma Müllera (Marek, 1952 s. 157). Tak więc zachodzi tu relacja, którą w skrócie opisać można zależnościami: tekst poetycki - muzyka - tekst poetycki. A. Hejmej zaznacza, że ten zbiór S. Barańczaka jest pełen niuansów, które wymagają jednoczesnego słuchania i czytania, by możliwe stało się ich odkrycie. Podkreśla także niezwykłą dbałość poety o możliwie najdokładniejsze odwzorowanie tego, co dzieje się w muzyce i jednoczesny dialog z niemieckim tekstem pieśni. To wszystko zyskuje miano "mikroskopowego konceptyzmu” (Hejmej, 2002, s. 134). Utwory S. Barańczaka nie są jednak tłumaczeniami wierszy W. Müllera. Tylko jedna pieśń - Lipa jest przytoczona dosłownie. 
Wilhelm Müller (Müller)

Die Post

Von der Straße her ein Posthorn klingt Was hat es, daß es so hoch aufspringt Mein Herz?

Was hat es, daß es so hoch aufspringt Mein Herz?

Mein Herz?

Die Post bringt keinen Brief für dich Was drängst du denn so wunderlich Mein Herz, mein Herz?

Die Post bringt keinen Brief für dich Was drängst du denn so wunderlich Mein Herz, mein Herz?

Nun ja, die Post kommt aus der Stadt Wo ich ein liebes Liebchen hatt' Mein Herz!

Wo ich ein liebes Liebchen hatt' Mein Herz, mein Herz!

Willst wohl einmal hinübersehn Und fragen, wie es dort mag gehn Mein Herz, mein Herz?

Willst wohl einmal hinübersehn Mein Herz, mein Herz? Und fragen, wie es dort mag gehn Mein Herz, mein Herz?

Stanisław Barańczak (Barańczak, 1994) XIII

Mój zegarku, niepotrzebnie drwisz: no, o czym znów zapomniałem dziś na śmierć?

No, o czym znów zapomniałem dziś na śmierć, na śmierć?

Mam wziąć pigułkę? wysłać czek? Obalić Zło? wynaleźć lek na śmierć? 
na śmierć?

na śmierć?

Mam wziąć pigułkę? wysłać czek?

a śmierć? a śmierć?

I skazać Zło, i znaleźć lek na śmierć?

na śmierć?

na śmierć?

Czy to elektroniczne "bip",

czy jakiś inny mowy typ

zna śmierć?

czy jakiś inny mowy typ

zna śmierć,

zna śmierć?

Czy szept, czy wagnerowski głos?

I czy do powiedzenia coś

ma śmierć,

ma śmierć?

Czy szept, czy wagnerowski głos

ma śmierć,

ma śmierć?

I czy do powiedzenia coś

ma śmierć,

ma śmierć

Nietrudno dostrzec interferencję tekstu muzycznego i słownego, która staje się dodatkową warstwą podlegającą analizie i interpretacji. Ta zależność świadczy o wielowarstwowości dzieła. W tym przypadku S. Barańczak jasno wskazuje na źródło swojej inspiracji i dzięki temu łatwiej jest ustalić status utworu jako całości, znając jednocześnie kierunek oddziaływań intertekstualnych (tekst S. Barańczaka - tekst W. Müllera), czy nawet intermedialnych (tekst S. Barańczaka - utwór muzyczny Franza Schuberta). Nie chodzi wyłącznie o kwestie związane z genologia, lecz o ontologiczny status dzieła literackiego, który zmusza badaczy do podjęcia refleksji o zgoła odmiennym charakterze niż literacki.

Relacje pomiędzy muzyką a dopisanym do niej tekstem można wyjaśnić zatem za pomocą terminu kontrafaktura. Kontrafaktura, czyli technika zastępowania tekstu zupełnie nowym, dopisanym do muzyki z uwzględnieniem wszystkich formalnych elementów (metrum, rytmu, akcentów, itd.) konstruowanych w tekście za pomocą środków literackich. Spojrzenie to wydaje się tym bardziej zasadne, że S. Barańczak dodaje podtytuł: Wiersze do muzyki Franza Schuberta, który sugerować może badanie utworów pod takim kątem. Na początku tomu umieszcza także podpowiedź dla czytelnika, która wyjaśnia rolę muzyki w kształtowaniu poezji: „Choć związek między 
moimi utworami a muzyką Schuberta jest bardziej intymny i ścisły, moją ambicją było napisanie takich tekstów, które można byłoby zaśpiewać do określonej melodii a zarazem - przeczytać również w oderwaniu od muzyki, jako samodzielne wiersze" (Barańczak, 1994, s.7).

Autor tłumaczy także proces powstawania swoich dzieł. Zaznacza, że jego celem nie było parafrazowanie pierwotnych pieśni. Większość utworów napisanych przez S. Barańczaka ma charakter fonetów. Poleca on zapoznanie się symultaniczne z wierszem i muzyką, podkreślając tym samym palimpsestowość tekstów. S. Barańczak uwzględnił też cytaty muzyczne, przybierające formę muzycznych incipitów oraz numery, które stanowią odwołanie do konkretnych pieśni F. Schuberta. Wobec tego każdy utwór autora Chirurgicznej precyzji to zarówno "wirtualny tekst wokalny" (tekst słowny będący częścią kompozycji muzycznej) sugerowany przez podtytuł oraz tekst literacki sugerowany przez tytuł (Hejmej, 2002, s. 125).

Oprócz schematu stricte muzycznego na wiersze nakłada się schemat rytmiczny i syntagmatyczny tekstów W. Müllera. Przedstawię to na przykładzie pieśni XIII. Widać w niej wyraźnie tę palimpsestową strukturę, która objawia się dopiero w momencie jednoczesnego słuchania i czytania. Fakt, że wiersz S. Barańczaka oparty został na ścisłym schemacie rytmicznym (występują tu jamby $\mathrm{i}$ trocheje $\mathrm{z}$ nielicznymi wyjątkami w postaci anapestu), warunkuje również struktura muzyczna. Rymy męskie, na których zbudowany został szkielet dzieła, powiązane są z akcentem oksytonicznym, co z kolei dodatkowo znajduje uzasadnienie w muzyce. W pieśni XIII zachodzi zgodność rytmiczna, akcentowa oraz intonacyjna z pierwowzorem. Na jeden dźwięk widoczny w zapisie nutowym przypada zazwyczaj jedna sylaba tekstu, zwykle akcentowana tak jak tekst oryginalny („Von” - „Mój', , der-Stra-sse” - „ze-gar-ku” itd.). Również intonacja jest znakomicie oddana. Wszędzie tam, gdzie w tekście słownym pojawia się znak zapytania, w muzyce widzimy wznoszenie się linii melodycznej i nagromadzenie pauz.

Kursywa w utworze XIII jest wyróżnikiem powtórzeń fragmentów tekstu występujących także u F. Schuberta. Można powiedzieć zatem, że wiersz idealnie „przystaje", nakłada się na pieśń F. Schuberta, a poeta uwzględnia dokładnie wszystkie repetycje.

Tonacja utworu (Es-dur) nadaje charakter patetyczny, ale nieco ironiczny i szorstki. Barańczak dopasował temat wiersza do słyszanej melodii. Opisuje zegarek, który "drwiąco" przypomina o upływie czasu, o nieuchronnie zbliżającej się śmierci. Ukazuje też zawodność ludzkiej pamięci, ponieważ to zegarek "elektronicznym «bip»" przypomina o „wzięciu pigułki”, „wysłaniu czeku”, ,wynalezieniu leku”, ,obaleniu Zła".

Brzmienie ośmiu pierwszych taktów pieśni Die Post kojarzy się z cwałem koni. Jest to o tyle zasadne, że $6 / 8$ jest porównywalnym metrum cwału. U S. Barańczaka wrażenie pędu powoduje nie tylko rytm wiersza, ale także metafora przemijania i świadomość upływającego czasu, o którym przypomina zegarek. Tekst staje się bardzo dynamiczny. Przejmuje także emocjonalny ładunek, którego nośnikiem jest muzyka. Dzieje się tak również za sprawą tempa określonego jako „etwas geschwind”, co rozumieć należy jako trochę szybciej w odniesieniu do poprzedniej, XII pieśni, którą kompozytor zapisał w tempie „langsam”, czyli wolnym. 
F. Schubert muzycznie opisuje sytuację, gdy do miasta, z którego wraca wędrowiec, przyjeżdża dyliżans pocztowy. Chłopiec mija dyliżans i kiełkuje w nim nadzieja na otrzymanie wiadomości od ukochanej, którą zostawił w mieście. Okazuje się jednak, że nie ma dla niego żadnej wiadomości i nie ma już powrotu. Zaczął swoją podróż zimową i musi ją skończyć, za towarzyszy mając tylko krążące i wyczekujące łupu wrony (1952, s. 159).

Świetnie w ten kontekst wpisuje się wizja S. Barańczaka opatrzona zwrotami „,na śmierć", które w pewnym momencie za sprawą melodii zdają się być nostalgiczne. W pierwowzorze słowa „mein Herz" występują osiemnaście razy dokładnie w tej samej formie. U S. Barańczaka widzimy wariantywność - zmiany, które sprowadzają na myśl inny kontekst semantyczny. W istocie, inaczej „znaczy” stwierdzenie „na śmierć” niż „zna śmierć” lub „ma śmierć”. Za sprawą pierwszej strofy dowiadujemy się, o czym podmiot liryczny na śmierć zapomniał. Zestawienie obu słów jest wówczas częścią frazeologizmu. Druga strofa przynosi domniemania na temat leku, który zapobiec mógłby umieraniu. W pierwszej części trzeciej zwrotki powtórzone zostały pytania, będące wyrazem niepewności i marności człowieka zestawionego na zasadzie kontrastu ze zjawiskiem śmierci. Czwarta strofa natomiast jest refleksją na temat językowych i para językowych zjawisk oraz wątpliwości dotyczących ich końca. Parafrazując: czy jakiś język może umrzeć, zaniknąć? Ostatnia strofa i zawierająca się $\mathrm{w}$ niej sekwencja powtórzona po trzykroć jest wyrazem zastanowienia nad sensem śmierci. Widzimy zatem różnorodność i paradoks, który ukazuje się dopiero po zestawieniu z pierwowzorem. Oprócz zróżnicowania semantycznego omawianych wariantów, S. Barańczak stara się, aby były one podobne brzmieniowo do oryginału („,mein Herz" - „na śmierć”, ,"a śmierć”, „zna śmierć”). Nadmienię tylko, że każdy wariant pojawia się dokładnie wtedy, gdy w oryginale słyszymy "mein Herz".

Schematy rytmiczne, na których pojawiają się słowa "mein Herz", są stopniowo rozbudowywane. Jest to o tyle istotna kwestia, że właściwie tylko opracowania tych wyrazów są różnorakie i znacząco wybijają się na tle innych, powtarzających się schematów rytmicznych - zwykle obejmujących ćwierćnutę i cztery ósemki, po których następuje sekwencja przeplatających się ćwierćnut, ósemek i pauz w różnej konfiguracji - w całości utworu. W omawianych przeze mnie fragmentach (i tylko w nich) pojawiają się także wartości dłuższe niż ćwierćnuta z kropką. Słowo „Herz” zwraca więc uwagę słuchacza, ponieważ występuje zawsze na mocnej części taktu i opracowane zostaje w muzyce za pomocą długich wartości rytmicznych. Dlatego też tak wielkie znaczenie zyskuje słowo „śmierć” używane przez S. Barańczaka.

Pieśń Die Post podzielona jest na dwie, powtarzające się części - A i B (cała struktura przyjmuje kształt: $\mathrm{ABAB}^{\prime}$ ). Wiersz odzwierciedla tę budowę. Ponadto pierwsza strofa wiersza tematycznie odpowiada czwartej (byłaby to część A), natomiast strofa druga odpowiada trzeciej (część B).

Pierwsza częśćutrzymanajest $w$ charakterze narastającego niepokoju, co wyraża się w tekście wprowadzeniem pytania: „,o czym znów zapomniałem dziś/naśmierć?”. Niepokójniejesttakprzejmujący,jakwczęścidrugiej,ponieważmelodiazawieranutęnadziei. Zapierwszym razemna ostatniąmiaręczternastegotaktu widzimy modulację dotonacji Des-dur tam, gdzie występują słowa "na śmierć". Drugi zwrot widnieje w 21 takcie i opatrzony jest akordem przesuniętym o sekundę małą w dół względem następnego. 
Jest to zatem akord alterowany wyróżniający się kolorem na tle innych. Począwszy od tego taktu, we wszystkich miejscach, gdzie poeta wpisze powyższy zwrot, występują coraz bardziej złożone i zabrudzone akordy. Ostatnia prezentacja tego motywu odbywa się już za sprawą grania akordów: B-dur lewą ręką i F 7 prawą, co powoduje wrażenie złożoności tych brzmień.

Druga część jest bardziej nostalgiczna, muzycznie przypomina szereg pytań. Tonacja zmienia się na mollowa, żałobną, grobową (es-moll), co wywołuje u słuchacza spotęgowane uczucie niepewności, ponieważ według klasycznych kanonów, w tej części pieśni powinna pojawić się tonacja dominanty, czyli tonacja B-dur lub paralelna do niej c-moll. Tym wyraźniejsze stają się więc szeregi pytań i tym dobitniej wybrzmiewa słowo „śmierć".

Części A i B oddzielone są w pieśni jednotaktową pauza, która jest zapowiedzią przeobrażenia charakteru. W części B zmienia się nastrój, charakter, artykulacja, zanika rytm punktowany. Melodia staje się wyrazem rozżalenia, niestabilności (pojawiają się dźwięki obce, nienależące do tonacji es-moll oraz przejściowe) a potem nawet wzburzenia i bezsilności. W wierszu Barańczaka wyrażone jest to za pomocą szeregu wątpliwości. Kolejne pytania wydają się coraz głośniej wypowiadane, by potem znów przejść do bezsilnego piano.

Niewątpliwie jednym z celów poety było oddanie własnych emocji, przeżytych pod wpływem kompozycji muzycznej, lecz należy zauważyć, że S. Barańczak na tym nie poprzestał. Na bazie swoich doznań zbudował tekst niejako alternatywny, dopasowany do muzyki, pozostający także w relacji z tekstem pierwotnym W. Müllera. Oprócz tego celem wierszy stało się oddanie jakości ponadczasowych i tych ironicznie komentujących rzeczywistość. Toteż Podróż zimowa jest wyrazem rozrachunku bohatera (jadącego samochodem i słuchającego muzyki) ze światem, w którym zwykłość, codzienność i doświadczenia metafizyczne wcale się nie wykluczają. Przeciwnie - trywialność, zderzając się z artyzmem i duchowością stwarza świat, jaki znamy.

W Chirurgicznej precyzji (Barańczak, 1998) wyróżnić można kilka rodzajów występowania muzyki, które w zasadzie poddają się prostej analizie. Teksty mogą bowiem: nawiązywać bezpośrednio - za pomocą incipitów, tytułów utworów muzycznych, fragmentów dzieł muzycznych i innych intertekstów - oraz pośrednio do muzyki; mogą też zawierać konkretne nazwy genologiczne, np. w tytule: madrygał, piosenka, serenada, aria, alba; mogą przyjmować różnorodne formy, np. ronda, czy piosenki z refrenem; mogą pojawić się próby przekładu, polemiki z dziełem „pierwowzorem” (mam tu na myśli utwór, który jest podstawą do stworzenia tekstu poetyckiego), np. $\mathrm{z}$ wybraną arią konkretnego kompozytora; może występować także autorskie wskazanie na kompozytorów, muzyków, wykonawców.

Wiersz Tenorzy jest wyrazem dysonansu zachodzącego między sztuką a światem realnym, między absolutnym pięknem a trywialnościa, pomiędzy umiejętnościami a czynnościami codziennymi. Na początku podmiot liryczny zadaje pytanie, które jest właściwie metaforą dualizmu świata i człowieka; walczących ze sobą idei i tego, w jaki sposób doczesność je realizuje. Pytanie owo brzmi: „Tenorzy, czemu ja was kocham?/ Przecież wszyscy jesteście tłustawi" (Barańczyk, 1998, s. 20). Podmiot zastanawia się dalej, skąd w tak marnych, pocących się, tłustych, pospolitych postaciach bierze się umiejętność przenoszenia człowieka w wymiar piękna, absolutu, doskonałości. Po- 
stać tenora byłaby tu metaforą muzyki. Uwidacznia się pewna cecha uniwersalna, którą posiada sztuka, w szczególności zaś muzyka. Staje się ona „drabiną przenoszącą w obłoki”. S. Barańczak opisał ponadczasowość muzyki stwierdzając: „,są w tym raju na zawsze, zasłużyli, czy nie zasłużyli/ Caruso z podkręconym wąsikiem, brylantyną kapiący Gigli,/ Tauber w operetkowym cylindrze, grubas Lauritz Melchior" (Barańczyk, 1998, s. 20). Głos tenora jako przejaw ponadczasowości wznosi się na „krawędź cudu" a należy dodać, że jest to głos „pospolitego, przylizanego, tłustawego" mistrza McCormacka.

Odczyt nieuwzględniający przerzutni uwydatnia słyszalny rytm. Jest on miarowy, pulsacyjny, budowany przez podobną ilość sylab w wersach. To on stwarza wrażenie muzyczności. Przerzutnia zaburza rytm oparty na aliteracji i asonansach występujących zazwyczaj w obrębie rymu, ale nie tylko. Zaciera także wrażenie tętnienia, a tym samym muzyczności. Gdy uwzględnimy (przy głośnym czytaniu) przerzutnie, uzyskujemy wrażenie braku pauz, braku miejsca na oddech. Czujemy obecność dynamiki. Oczywiście to wrażenie jest subiektywne tak samo, jak subiektywne jest "odczuwanie" rytmu.

Eufoniczną strukturę utworu stanowią aliteracje, asonanse i instrumentacja głoskowa, które powodują nagromadzenie wielu podobnie brzmiących słów („,podbródki: podwójne, podwójnie pocące się", ,"pszenicę, w przemyśle, w przemycie”).

Zajmującą kwestią jest specyfika rymów oparta o te same, wyżej wymienione środki (tłustawi - ustami - rozhuśtani; grzędzie - ugrzęźnie - urzędzie, (w) przemycie - przemycie (szyby) - psie życie; blasku - obrazku - oklasków itd.) Wszystkie tego typu nagromadzenia tworzą obok wartości naddanej brzmieniowo, także warstwę dynamizująca.

W wierszu Chęci (1998, s. 35) ukazana jest struktura pieśniowa z wyraźnymi, powtarzającymi się zwrotkami i refrenami (dodatkowo wydzielonymi w tekście kursywą). Utwór zbudowany jest na powtarzających się konstrukcjach, słowach, zwrotach, zespołach brzmieniowych. Swoisty paralelizm składniowy staje się bazą dla przesłania, które wpisuje się we wcześniej wspominane konwencje. Już na samym początku, na pierwszy plan wysuwa się kunsztowność, konceptualizm oraz wirtuozeria formalna.

Pierwsza zwrotka kreśli zakres tematyczny utworu. Stwórca (nazywany potem także Projektantem, Autorem, Brakarzem - oceniającym i kontrolującym jakość, Wykonawcą) jest konstruktorem idealnie działającej biologicznej machiny złożonej z wielu fizjologicznych trybików. Tą machiną jest Ciało. W drugiej zwrotce opisana jest Dusza jako machina analogiczna, która „wzrusza samego genialnego Stwórcę". Nawiązuje się tu dialog pomiędzy Duszą a Ciałem, których stworzycielem jest geniusz, a które skazane są na „,chorobę", czyli defekty w działaniu. Paralelizm zwrotek polega na powtarzalności podobnych brzmieniowo, lecz odmiennych semantycznie członów: „,od Aort do Żeber" — „od Aprobat do Żalów”; ,polirytmia skurczów i rozkurczów" - „polifonia podszeptów-pouczen"”; ,inżynieria płuc, nerek, przyspieszonych kursów/ krwi" - „dynamika przepływu pokuty w pokusę/ gry"; , ,aby wydalić to, co niepotrzebne" - „aby oczyścić go z mentalnych kałów”; "Ciało” - „Dusza” (Barańczyk, 1998).

Klarują się zatem dwa porządki przypisane człowiekowi: cielesny i duchowy, które narażone są na porażkę: „gdy któraś cząstka ciała ustanie, nawali,/ zaboli, czy okaże

Ogrody Nauk i Sztuk nR 2020 (10) 
się śmiertelnie chora?” - „kiedy jej cząstka zdradzi, zawiedzie, nawali,/ uświęci okrucieństwo, z nienawiści chora?". Pomiędzy zwrotkami nawiązują się następne zależności: wers pierwszy pierwszej zwrotki jest symetryczny względem wersu pierwszego drugiej zwrotki, wers drugi odpowiada drugiemu, trzeci - trzeciemu itd. Tak samo jest w przypadku intonacji. Koniec obu zwrotek stanowi pytanie, czy Ciało i Dusza odpowiadają („muszą się rumienić”) za zdradę jakiejś cząstki. Refren zdaje się być na nie odpowiedzią: „Przeciwnie [...] liczą się chęci”.

Paralelne okazują się też względem siebie refreny. Oprócz tego, że wersy rymują się wewnątrz danej zwrotki, to także końcówki wersów pierwszego refrenu rymują się z odpowiadającymi im końcówkami w refrenie równoległym: „zranieni” - „zdumieni”, „,ból nazbyt ich męczy” - „zawód zbyt ich dręczy”(Barańczyk, 1998). Reszta powtarza się w niezmienionej postaci.

Znaczące są terminy nacechowane muzycznie, które S. Barańczak wykorzystuje - polirytmia i polifonia. Właściwie tak można ująć skrótowo zjawiska występujące w tym tekście. Budują je takie środki jak: homonimicznie brzmiące wyrazy, konstrukcja strof oraz refrenów, będąca wyrazem paralelizmu syntaktycznego, podobnie układające się akcenty oraz podobieństwo intonacyjne, wreszcie dynamika sprawiająca wrażenie tętnienia. Efekty te zarazem budują kontrast semantyczny, który wysuwa się na plan pierwszy.

Nie sposób nie zauważyć różnic dzielących przedstawione powyżej analizy. Pierwsza z nich uwzględnia prezentowaną, symbiotyczną metodę opisu dzieła o charakterze literacko-muzycznym, w której z założenia posługujemy się narzędziami, jakie dostępne są literaturoznawcom i muzykologom. Drugi sposób analizowania $\mathrm{w}$ zasadzie nie wymaga posiadania kompetencji muzykologicznych, ponieważ prezentowane teksty nie wykazują tak rozległej muzycznej organizacji. Jednakże i tu zauważalny staje się swoisty eklektyzm badawczy, niezbędny przy analizowaniu i interpretowaniu utworów uwikłanych w muzyczne odniesienia

\section{Bibliografia}

[1] Barańczak, S. (1998). Chirurgiczna precyzja. Elegie i piosenki z lat 1995-1997. Kraków: a5

[2] Barańczak, S. (1994). Podróż zimowa. Wiersze do muzyki Franza Schuberta, Poznań: a5.

[3] Dąbrowski, S. (2002). Muzyka w literaturze (Próba przeglądu zagadnień). W: Hejmej, A. (red.), Muzyka w literaturze. Antologia polskich studiów powojennych (ss. 145-169). Kraków: UNIVERSITAS.

[4] Hejmej, A. (2002). Muzyczność dzieła literackiego. Wrocław: Wydawnictwo Uniwersytetu Wrocławskiego.

[5] Hejmej, A. (2012). Muzyka w literaturze. Perspektywy komparatystyki interdyscyplinarnej. Kraków: UNIVERSTTAS.

[6] Głowiński, M. (2002). Literackość muzyki - muzyczność literatury. W: Hejmej, A. (red.), Muzyka w literaturze. Antologia polskich studiów powojennych. (ss. 101-121). Kraków: UNIVERSITAS.

[7] Golec, M. (2018). Dwa żywioły? O strategii badań i związkach muzyki zliteraturą. Radzyński Rocznik Humanistyczny, 16. Pobrane z: http://cejsh.icm.edu.pl/cejsh/element/bwmeta1.element.desklight-cbe0b3b9-2371-4f2c-91f7-45a435e68cd0/c/dzida_2018_2.pdf

[8] Gołąb, M. (2012). Spór o granice poznania dzieła muzycznego. Toruń: Wydawnictwo Naukowe Uniwersytetu Mikołaja Kopernika.

[9] Lachman, M., Wiśniewski, J. (2012). Poszerzanie pola styszenia. (ss. 5-7). Łódź: Acta Universitatis Lodziensis. Folia Litteraria Polonica 15. Pobrane z: http://dspace.uni.lodz.pl:8080/xmlui/bitstream/handle/11089/2296/00-wstep $\% 5 b 1 \% 5$ d. pdf? sequence=1\&isAllowed=y

[10] Marek, T. (1952). Franciszek Schubert, Kraków: PWM. 
[11] Mianowski, J. (2000). Semantyka tonacji w niemieckich dziełach operowych XVIII-XIX wieku, Toruń, Wyd. Adam Marszałek.

[12] Nycz, R. (1990). Intertekstualność i jej zakresy: teksty, gatunki, światy. Pamiętnik Literacki: 81, (ss. 95-116 ).

[13] Opalski, J. (2002). O sposobach istnienia utworu muzycznego w dziele literackim. W: Hejmej, A. (red.), Muzyka w literaturze. Antologia polskich studiów powojennych. (ss. 171-190). Kraków: UNIVERSITAS.

[14] Reimann, A. (2012) Muzyczny styl odbioru - muzyczny interpretant - literacka forma muzyczna. Pobrane z: https://repozytorium.amu.edu.pl/bitstream/10593/3780/1/09Reimann-pp.pdf

[15] Schubert, F. (1827-1828). Franz Schubert's Werke. Erste kritisch und durchgesehene Gesammtausgabe. [Dzieła Franza Schuberta. Pierwsza krytyczna i sprawdzona edycja]. Leipzig: Breitkopf \& Härtel.

[16] Tomaszewski, M. (2003). Muzyka w dialogu ze stowem. Próby, szkice, interpretacje. Kraków: Akademia Muzyczna.

[17] Müller, W. Die Post. [Poczta]. Pobrane z: https://www.zgedichte.de/gedichte/wilhelm-mueller/die-post.html 

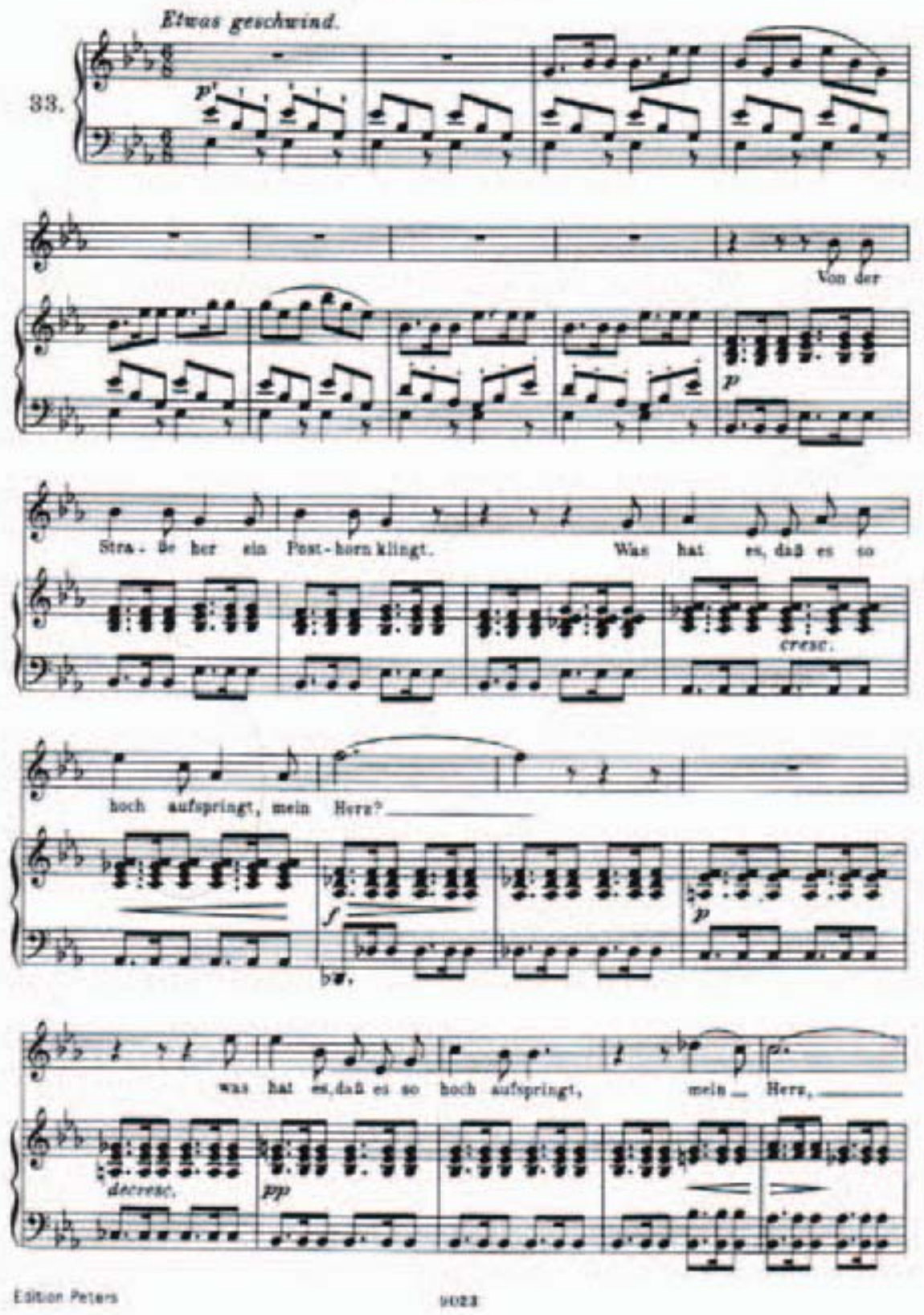


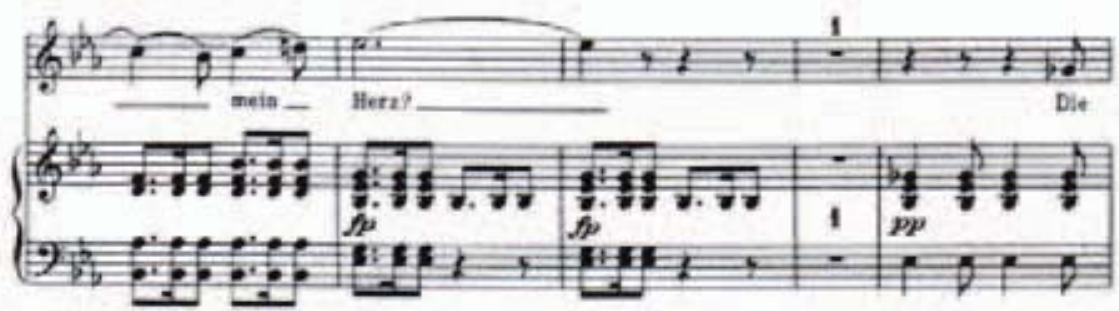

(6)
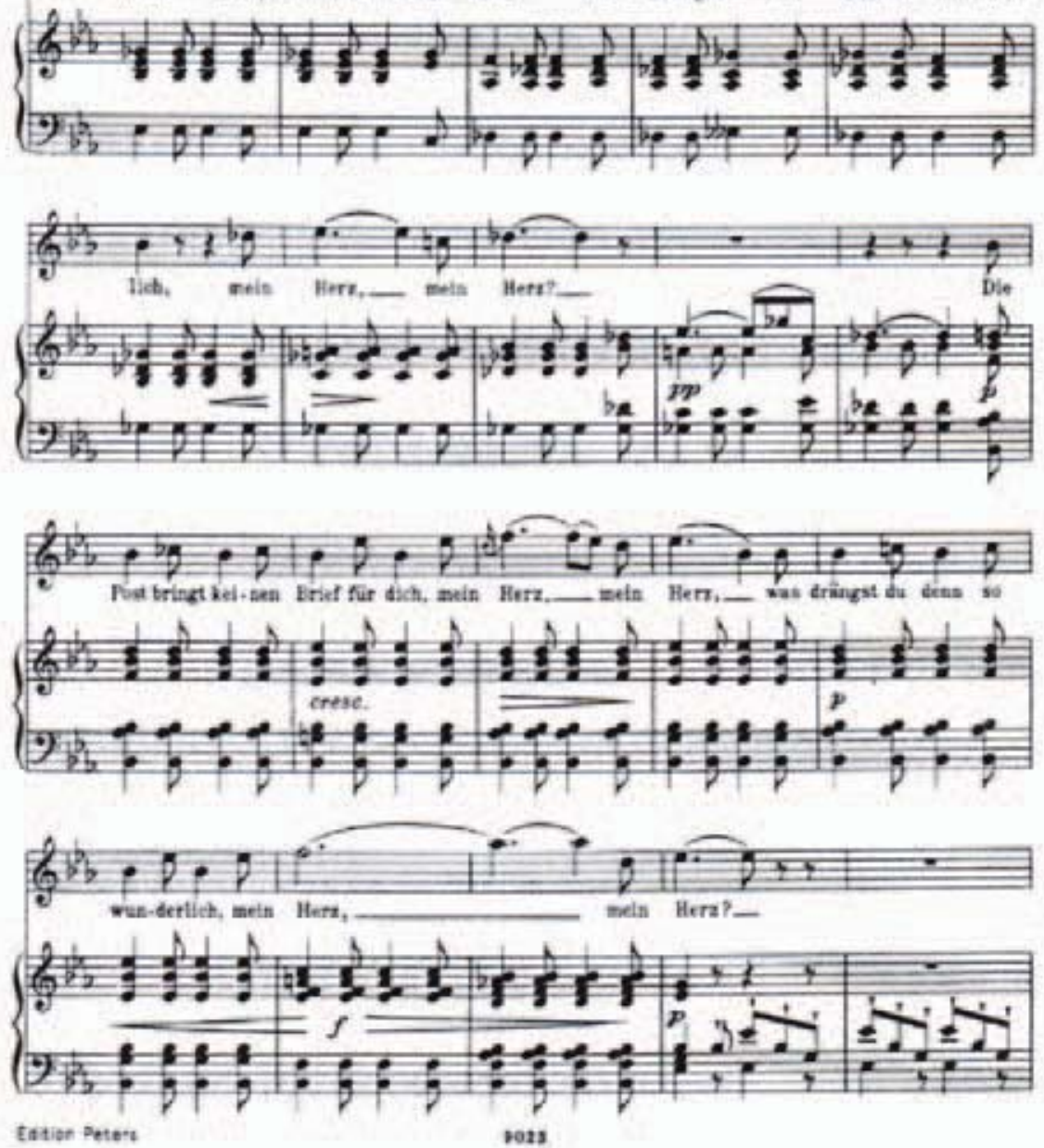

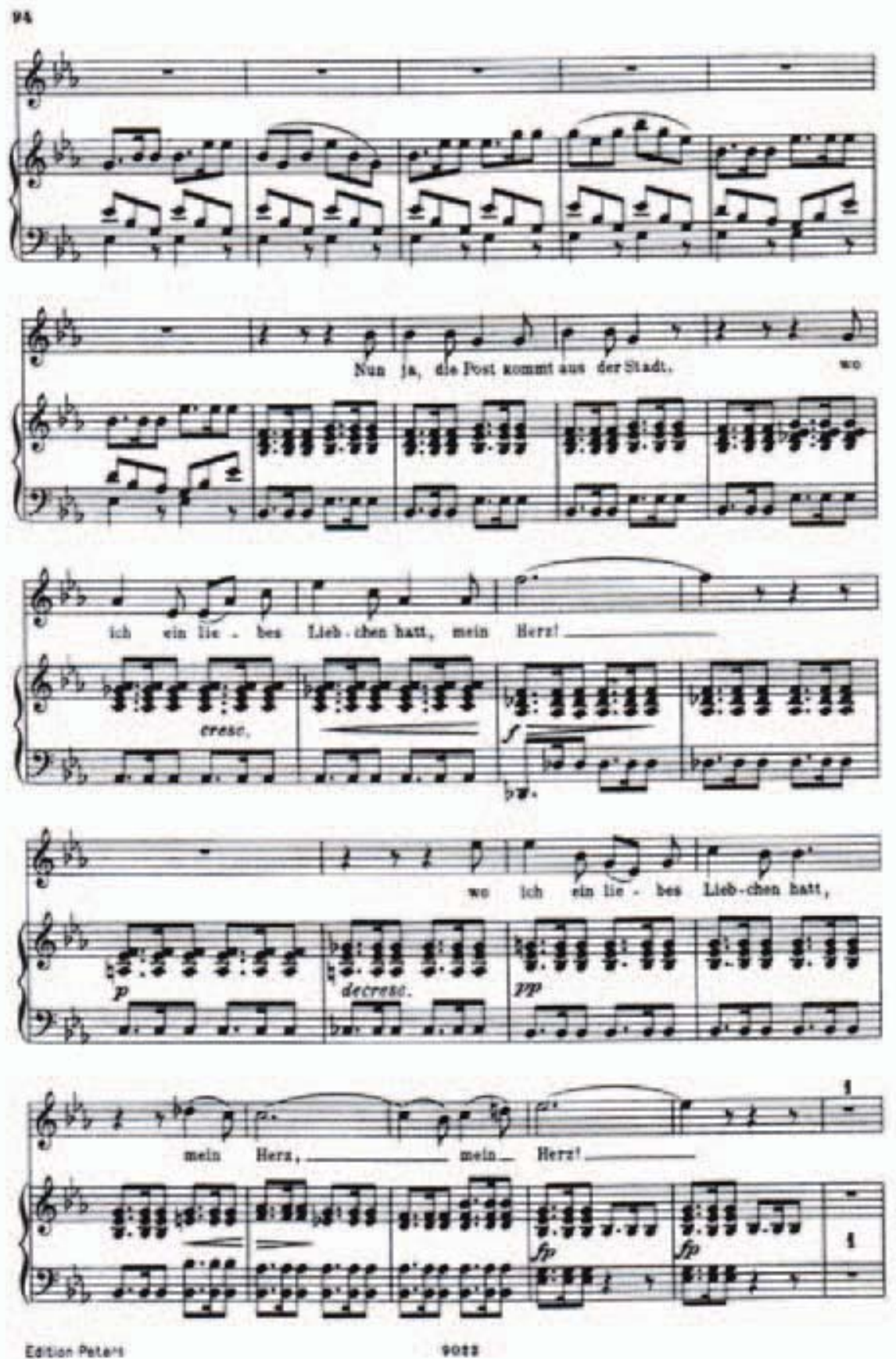

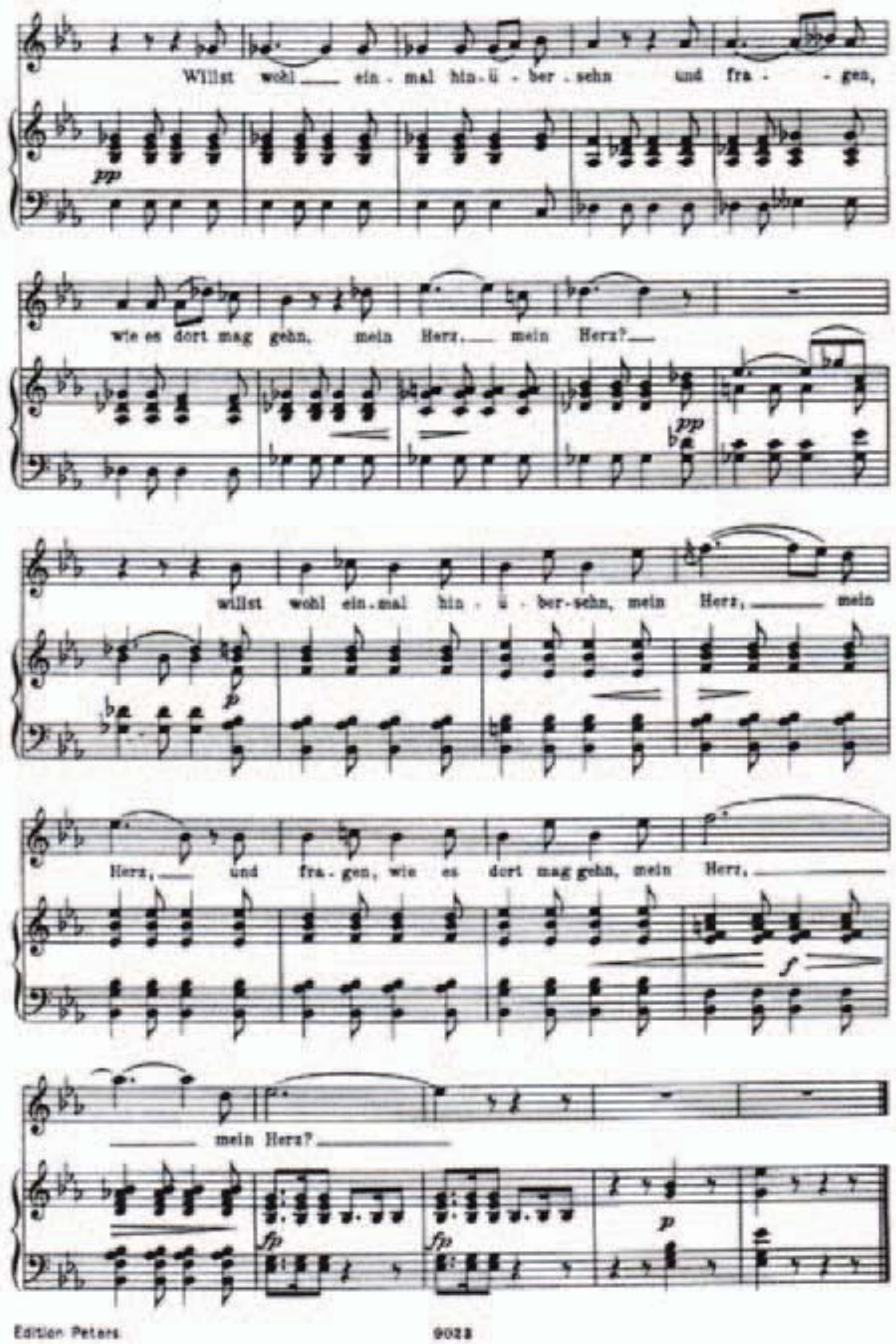

Rysunek 1. Die Post (pieśń XIII) - Winterreise, op. 89.

Ogrody Nauk i Sztuk nR 2020 (10) 